\title{
EXPLANATORY GUIDE
}

Something must be said about the arrangement, mechanics, scope and limitations of this Catalogue. It is in three Sections:

I. An Alphabet of Authors, describing their first (and certain subsequent) editions, with a subsection 'Comparative Scarcities'.

II. The Yellow-back Collection, arranged in a mixed alphabet of Authors' Names, Series-titles and a few group-headings.

III. 'Novelists Libraries', 'Standard Novel' Series and Collections of Tales, alphabetically listed under the key-word in the title of each such Library or Series.

All three Sections are primarily concerned with books actually in the Collection, but in each one some titles not present have been added. In Section I this has been done where the run of first editions of any one hitherto unbibliographised author (whether of his complete works or of his fiction*) is very nearly complete. In order to compile a complete bibliography of such an author, I have obtained from some outside source (usually a Statutory Library) a description as nearly accurate as possible of the missing titles. In Sections II and III titles not in the Collection are added to the lists of several important Series, the record of which must, if it is to be of referencevalue, be made as complete as possible. In every case, and in each Section, items recorded but never in my possession are distinguished by asterisks.

As regards scope and limitations, those must first be clearly understood which govern the Catalogue as a whole, and then those relevant to the three Sections. The choice of Authors for inclusion has been governed by three quite simple rules. Any novelist whose writing-life was comprised within the limits of the nineteenth century is entitled to a place, assuming of course that he was represented in the Collection. No novelist who published fiction prior to the year $\mathbf{1 8 0 0}$ has been admitted. $\dagger$ Any writer who began publishing late in the century and issued a fiction in two or three volumes (provided a novel by him or her in this form was in the Collection) has been regarded as eligible for inclusion.

My interpretation of 'eligibility' has, admittedly, been arbitrary and personal. In some cases fiction by authors who really belong to the later one-volume period, but chance to have one or two early titles issued in two- or three-decker form, is given full treatment (e.g. Harland, Hudson, Pryce, Mark Rutherford, Somerville and Ross) or treatment as full as the Collection allows (e.g. Bret Harte). In others, authors of the kind are only recorded up to, and including, the year 1900 (e.g. Doyle, Haggard, Flora Annie Steel). Authors fully established during the three-decker period, whose writing-lives nevertheless stretched well into the twentieth century, received extended treatment if I consider they merit it (e.g. Braddon, Broughton, Henry James, Ouida); but some are stopped at 1900, even though I had titles of later date, because their work does not in my view merit further pursuit (e.g. Hall Caine and Marie Corelli). An exception is made of Mrs Humphry Ward (who would normally have been closured in 1900) because the series of presentation copies to Bishop and Mrs Creighton are of sufficient interest to justify prolonging her catalogue to the year 1911. Finally, in several cases (e.g. Barclay, Everett Green, Fletcher, Marriott Watson, Moore, Philpotts) the author's single three-decker has been considered sufficient representation.

* Although the work is overridingly a catalogue of fiction, a certain number of non-fiction titles find a place in it. Where I can offer a complete record of the first editions of some significant author who is mainly known as a novelist, it seemed pedantic to omit his few non-fiction books and to that extent damage the utility of the list of his works.

$\dagger$ To this rule one near-exception has been made in Section I. Maria Edgeworth's first novel appeared in 1800, but she published during the eighteenth century two or three books which were in the Collection and are here recorded. 


\section{EXPLANATORY GUIDE}

Naturally I have not felt bound, in order to honour the second of my rules, to include every in-itself-admissible novel which may have been in my possession. To an enthusiast for novels published in Victorian shape a really fine copy of a work, though itself wholly negligible, can give pleasure; but to occupy space in a printed catalogue with particulars of books no one is ever likely to wish to remember would be wasteful of effort. On the other hand, many titles do appear, of which nothing is known or recollected. Each of these has in my view something of interest-whether textual or as a specimen of book-making or as evidence of publishing method-and seems in consequence worthy of record.

At the end of Section I is a subsection presenting lists of Comparative Scarcities of the first editions of the fictions (or the principal fictions) of the more important authors whose works are adequately represented in the preceding pages.

With a single exception, the condition that eighteenth-century publications shall be excluded is imposed on Sections II and III, as well as on Section I. That exception is HARRISON'S NOVELISTS MAGAZINE (1780-1788) in Section III. It would have been wilful, in a work purporting to record the Contents and bibliographical features of the principal 'Novelists' Libraries' of the nineteenth century, to ignore their grandiose prototype.

The caption 'Yellow-back Collection' given to Section II must not be understood too literally. It comprises books issued in all colours, styles and forms of non-cloth binding employed by publishers during the cloth-period. Thus, Section II includes pictorial boards on bases of yellow, white, pink and blue; decorated and lettered boards; stiffened and unstiffened wrappers. Each variety is recorded, as and when it occurs. Further, the Section contains nearly as many titles first published in one of these forms as it does straight reprints. It is not generally realised how many fictions (some by well-known authors) first made their appearance in boards or wrappers and, since throughout the Section first editions are typographically differentiated from reprints,* there will be no difficulty in distinguishing them.

Section III seeks to provide what I have often wished were available, i.e. descriptions and schedules of the contents of the principal Libraries of Fiction and Novel Series of the nineteenth century. Inevitably these are somewhat miscellaneous, and contain work both original and reprinted; but they are of much interest, alike as evidence of the continued vitality of certain authors or titles, and as stages in the development of cheap-edition publishing.

Naturally no complete list of nineteenth-century fiction Series has been attempted. Such a list would be enormously long and the greater part of it useless. I have, therefore, sought to select only those Series which have a bearing on publishing history; and though my selection may well be incomplete, it can, I think, claim to contain nothing that has not some justification.

But justifications vary, and therefore the fullness with which the Series are recorded varies also. For example, it would have been sheer waste of labour and space to provide a complete list of ROUTLEDGE'S RAILWAY LIBRARY, which only very rarely has textual importance, and as a piece of progressive publishing was a direct imitation of the PARLOUR LIBRARY. The latter, on the other hand, deserves and has received extended treatment. Similarly, BE N TLE Y'S S T A N D A R D NOVEL SERIES, as a collection of titles and as a publishing venture, so far outweighs in importance COLBURN'S MODERN NOVELISTS OF ROUTLEDGE'S STANDARD NOVELS that I have devoted several times as much space to it as to both the others put together.

One other point. At several places reference is made to the Bentley private catalogue. This remarkable compilation was the work of Mr Richard Bentley, ably assisted by Mr F. E. Williams who for many years worked in New Burlington Street. These two, between 1893 and 1923, working on the ledgers and records of the firm, drew up a descriptive, partially annotated and in the main accurate catalogue of its publications from 1829 to 1898. A very small edition of this

* First editions are in caps., reprints in caps. and l.c. 


\section{EXPLANATORY GUIDE}

catalogue was privately printed by the late Mr Bentley and labelled 'For Official Use Only'. I have to thank Mrs Bentley for kindly giving me access to a record which has proved very valuable in establishing dates, authorship, Series-details, etc. in connection with a number of Bentley books.

In the descriptive entries $I$ have tried to observe the following rules:

(a) Title and subtitle are given verbatim (though with standardised punctuation), but no further title-page wording.

(b) Where no size is given, the volumes are either (in the parlance of the period) 'Post 8vo' or what we now call 'Crown 8vo.' Larger and smaller formats are designated as '8vo' or 'small' or 'fcap' $8 \mathrm{vo}$, and where a book is quarto it is so described. I have purposely not gone into closer detail in this matter of sizes nor tackled the vexed question of whether a book, just because it is printed in twelves, should be described as 12mo, for such problems do not affect the identification of any particular issue of the books in this Catalogue.

(c) Where a book was published anonymously, or as 'by the author of', etc., or under a pseudonym, or in collaboration, or as 'Edited by' someone, the fact is stated. Where nothing is said, the author's name appears quite simply on the title-page.

(d) Publishers' imprints are abbreviated in all well-known cases. Certain obscure imprints are given in full. Where place of publication was elsewhere than London, the fact is stated and the place given before the publisher's name.

(e) Colour of cloth used on 'half-cloth-board' books is not given because the material employed, whether by the original publishers or by the novel distributors who bought sheets in bulk, had no overriding sanction. The same book may exist with spines of several different textures and colours, no one of which can claim priority or official prescription.

$(f)$ Details of blocking on covers are given only for important authors not elsewhere described or where significant variants or issue-points exist.

(g) Where no colour of end-papers is given, these are yellow or pale yellow or buff or white. Other colours are recorded throughout. Only in the case of a few important authors have I subdivided these shades.

(h) Books with title-pages undated are described as 'n.d.' If a date appears elsewhere (for example in a dedication or preface or-as sometimes-among advertisements), this date is added in round brackets. A date in square brackets has been established on external evidence.

(i) I have tried to be severe on blemishes in the copies described, and correspondingly restrained in words of praise. With very occasional exceptions, I have used only the terms 'very fine' and 'fine'. Both should be taken literally - the former as meaning virtually above criticism, the latter as something highly exceptional, but not peerless.* Where no description is given, the book lacks specific faults and would normally be described as very good indeed, or even fine, but it does not in my opinion really qualify for the latter epithet. Every book with Bentley provenance is labelled (B), and must be understood to be in pristine condition unless some flaw is recorded. Similarly, all yellowbacks catalogued are really fine unless otherwise stated, with a few exceptions among Series such as the PARLOURLIBRARY, HODGSON'S NOVELS, etc., where titles in imperfect state are listed as titles in order more clearly to achieve a complete record.

(j) Where a half-title or other leaf or leaves should precede title-page I have said so. No comment means that no half-title (or preceding leaf or leaves) is called for.

\footnotetext{
* It must be borne in mind that a cloth book can be 'very fine' and still have some trifling external defect such as a rust-spot or small scratch. The description applies to the over-all brilliance of gold and glaze and the sharpness of edges and blocking.
} 


\section{EXPLANATORY GUIDE}

I am afraid that absolute uniformity in the formulas used, and in the wording and arrangement of entries, has not been achieved. The annotations have been done over a long period, and it was impossible to prevent slight variations of phrasing and arrangement. I hope, however, that the same amount of information has been given throughout.

(k) The Index at the end of this volume is an index of titles in the Collection and of significant titles mentioned in Notes throughout the Author-Alphabet.

Throughout Section I, where indicated by book-plate or signature, I have noted the provenance of books described. Apart from the obvious interest (sometimes the evidential value as to priority of issue) of inscriptions or signatures dated contemporaneously with a book's publication, it seemed to me that users of the Catalogue might be glad to recognise a copy earlier noted by themselves, or perhaps to find the name of some connection or forbear of their own recorded as a previous owner. Then, as the entries accumulated, I found that this evidence of provenance connected up in a queer way and quite independently of the individual significance of the original owners. There emerged the names or initials of half a dozen persons-persons previously quite unknown to me-who at some time during the nineteenth century had been in the habit of buying three-volume, two-volume, or single-volume novels, and treating them with varying degrees of respect.

I do not, of course, include in this group of former proprietors such large-scale book-owners as Christopher Bellew, or the Prices of Rhiwlas, or George or Richard Bentley, or Coningsby Disraeli. Their books, and those from one or two other prolific or family sources, came to me in bulk and at specified times. They lack, therefore, the unexpected (indeed, until I began to relate them to one another, the unsuspected) interest of books bought up and down the country at any time during the last twenty-five years, and now-quite fortuitously-reunited.

To the inspired purchasers and scrupulous custodians of certain yellow-backs, volumes of boarded series and the like, reference has been made in the autobiographical essay which precedes this Preface. John Browne, J. R. Molineux and Mary Rumfitt are the triumvirate who rule this kingdom. But there are also a few cloth-bound-fiction addicts, and to them also I would like to pay the tribute they deserve. The care they lavished on their books was not wasted, and they will be no less scrupulously treated in future.

First come 'Moretino' (whowas he?); then the enthusiast for Henry James, of whom I know nothing but the initials 'L. M. V. de W.' and from whose collection I have never seen a book by another author; then Radclyffe Walters. All these three kept their books superbly. The last-named (who, like Mary Rumfitt, dated his signature in every book) would appear to have been the most recent of the trio to become a victim of posthumous dispersal. The great majority of the 'Walters books' were acquired during 1944 and 1945. And yet Under the Greenwood Tree, which belonged to Walters' collection, was bought ten years earlier!

Lady Georgiana Codrington's only failing was a habit-shared with (perhaps, in social aspiration, borrowed from) the Duke of Leeds-of writing her name in ink on the outside of cloth covers.* Lady Emily Fitzroy was kind to her books--kinder than 'Ingram' or 'Mary C. Ingram', who bought with discrimination but read a little roughly. The book-plates of Geo. Evelyn Cower and A. H. Christie nowadays survive, I am glad to say, less frequently than was at one time the case. When I began on nineteenth-century fiction, books from the Cower and Christie collections appeared oftener than specimens from other recognisable sources (I presume their libraries had been recently dispersed), and my zeal for titles outran my sense of condition. Neither gentleman was a stickler

\footnotetext{
* It is interesting to find her mentioned in the first volume of Osbert Sitwell's autobiography, Left Hand, Right Hand, as the half-sister of the Sitwells' grandmother Lady Londesborough. She lived at Doddington Park, near Bath, and her books $\rightarrow$ so far as $I$ had the luck to come across them-were scattered among the Bath bookshops.
} 


\section{EXPLANATORY GUIDE}

for cleanliness or even for original state, and much replacement was necessary to bring what were once Cower or Christie items up to a satisfactory standard of unimproved normality.

A second non-bibliographical interest emerges from an examination of this considerable assembly of nineteenth-century fiction.

There take shape several subject-groups which cut across authorships and have a chronology of their own. These groups are of different kinds. Some formed themselves without conscious effort on my part; others resulted from a deliberate collecting pursuit. One or two have no cohesion save the theme common to all their members; the majority can be related to some historical happening, some new exploring enterprise, some specific outburst of social protest, even to some sudden popularity of a particular sport.

To the first category belongs the group of novels of School and University life-a group which is a respectable example of spontaneous accumulation. From Arnold's Christ Church Days to Mrs Henry Wood's Orville College it persists throughout the alphabet; and unusual specimens appear under Annie Edwards, Hewlett, Lister, Melly and Winwood Reade, as well as the more widely known books of Cuthbert Bede, Dean Farrar, Thomas Hughes and Henry Kingsley.

Roughly analogous is the spasmodic sequence of novels reflecting the perpetual conflict between Protestant and Catholic. This series of fictions merges on the one side into those concerned with Ireland and the Irish question (of which more below), on the other into stories of clerical life and vaguely religious colouring. But it retains a core of mutual disputatiousness and eager selfjustification to which both sides contribute. In addition to the well-known books by Mark Rutherford, Shorthouse and Mrs Humphry Ward, works belonging to this central core will be found under Archdeacon, Beste, Reynolds, Sinclair, and the section headed 'Authorship Unknown'.

Of the second and more numerous category of subject groups-representing the Schwärmereien which, at different epochs and at the prompting of various events at home and abroad, possessed our novel-reading forbears-it suffices to mention, and briefly, a few only. There are the stories of Persia and the near Orient (Morier, Baillie Fraser); the stories, spaced over a longer period, whose theme is India (Hockley, Meadows-Taylor, Flora Annie Steel); tales of the Sea and of life in the Navy; tales of the Wars and of life in the Army; propaganda novels written in defence of the down-trodden; novels of the Race Course and the Hunting Field.

There is, however, one specimen of period-fashion in fiction-making which merits a few paragraphs of comment-the craze during the twenty years preceding 1848 for what are familiarly known as 'Silver Fork' novels.

I have already recounted the opportune disposal of the Rhiwlas library, which made it possible for me to acquire a representative selection of these highly ephemeral fictions. I would now venture a brief comment on their intrinsic quality and interest.

In my opinion, these books, though frequently absurd, deserve more attention than they have yet received. An American student has published a monograph on the subject which gives evidence of much careful research and has value as a work of reference.* But its reading quality is flat, because it lacks the understanding of the English social background from 1825 to 1840 essential to an appreciation of a class of novel whose significance is more social than literary. The Silver Fork School (if a jostle of writers so predominantly amateur can be termed a 'school') produced a higher proportion of downright bad novels than any similar group, with the possible exception of the Gothic Romancers; but the flimsiest and gaudiest specimen bears inevitably the marks of the hectic period which produced it. Snobbery, title-hunting, parvenu-arrogance, the worship of fashion, the

* The Silver Fork School, by Matthew Whiting Rosa. Columbia Univ. Press, 1936.

xxxi 


\section{EXPLANATORY GUIDE}

aping by mushroom-aristocrats of the manners of aristocracy at the expense of its spirit, all the shrill ferment of a post-war and pre-revolutionary carnival pervade these otherwise worthless books and give them documentary value.

Only one individual Silver-Fork novelist (and to her also reference has already been made) deserves survival in her own right. She is Catherine Frances Gore-Disraeli's 'full-blown rose of a woman'who gave Sunday parties at her flat in the Place Vendôme; whose piquante saucy daughter, Cecilia, played the flapper-coquette with young Coventry Patmore to such cruel effect that the shy tormented youth was driven almost to suicide. It may be that Hook must be regarded as the founder of the School; it is certain that Disraeli and Bulwer and Frances Trollope wrote novels which rank as School-products; but no one of these claims survival as a Silver Forkist. Mrs Gore, on the other hand-apart from some early 'costume' work and a few tales of foreign lands-devoted her considerable talents during a long and active life to the delineation of precisely the gilded absurdity which during the thirties and forties was known as the ton. Further, being herself a woman of fashion who was also a gentlewoman, she knew what she was writing about and that all was not gold which glittered. Her novels are usually too long for their content (she was no rebel and, if publishers and libraries asked for three volumes, three volumes they should have), are often written in careless haste, and pretend to be only what they are-the caustic comments of a witty and observant woman on the vagaries of feminine character and on the follies of a society and an epoch of which she was well qualified to write. But, as such, they have humour, epigram, and a perceptive malice which is almost frightening.

It is unlikely that Mrs Gore will ever be reprinted. She is too loose in texture, too topical in reference, too dated in implication to be a 'revival' proposition. But no student of social history during the two garish decades when the jumble of ennobled profiteers, lickspittles and impoverished gentry staged a pseudo-eighteenth century jamboree can afford to neglect her books. The difficulty will be to find them.

In conclusion, I wish to draw attention to one particular section of this Novel-Collection, partly because I regard its successful assembling with unashamed complacency, mainly because it has an importance far transcending that of any of the subject-groups above mentioned. Here is a representative collection, in original (and for the most part in fine) condition, of the works of the novelists of Ireland. These Irish novels do not represent a response to some sudden new awareness, whose very novelty spells transience, but constitute a national literature in terms of fiction and, as such, have permanent significance. Their authors, from Maria Edgeworth to Somerville and Ross, include writers of every shade from the now despised Anglo-Irish to the now venerated nationalists.

Ideological labels toliteratureare distasteful to me. The quality of such novelists as Miss Edgeworth, Lady Morgan, Miss Somerville, Le Fanu, Lever, Maxwell, is something as independent of their attitude (or indifference) to Irish political and religious disputatiousness as is the quality of Carleton, Lover, or other contributors to Duffy's 'Library of Ireland'. Similarly the half-way-houseness of Griffin and the Banim Brothers is as irrelevant to their writing achievements as it would be if they had been Highlanders or Bashi-basouks. Irish fiction comprises much fiction of genius; but it is a literary genius, with superb local material superbly used. Its attitude to Pope or Protestantism or England or Orangism or Ribbon-Men or Absentee Landlords or any one of the bones of contention of that bony and contentious race, is in my opinion altogether beside the point. 